Filozofska fakulteta Univerze v Ljubljani

nickstanciu@yahoo.com

\title{
SOME DIFFICULTIES EXPERIENCED BY SLOVENIAN STUDENTS LEARNING ROMANIAN
}

\section{INTRODUCTION}

It is well known in linguistics that awareness of one language affects how certain goals are set (Frank \& Rinvolucri 1983; Hawkins 1984; Donmall 1985; James \& Garrett 1992; Schmidt 1995; Andrews 2003; Svalbeg 2007): finding common points between a native language and foreign language, increasing communication between the native language and foreign language, creating a common lexis, and promoting and understanding the characteristics of languages as part of life (James \& Garret 1992: 27). This also involves achievements and the affective, social, and cognitive domains. Language teaching is an activity that presumes grammatical internalization, not only as a pure cognitive act, but as both affective and cognitive to the same degree (Frank \& Rinovolucri 1985: 48).

At the same time, foreign-language teachers need to have certain qualities: a wish to work with linguistic topics, a strong wish to work on perfecting their teaching skills, and an intuitive understanding of the importance of language. Instructors teaching a foreign language assume a triple position: they are simultaneously language users, language analysts, and linguistics instructors (Cots \& Arno 2005: 61).

\section{GOALS}

This article presents some of the difficulties encountered while teaching Romanian as a foreign language at the University of Ljubljana, Slovenia. The theoretical framework for the description is functional-cognitive grammar, which presumes a multilevel approach to languages, a complimentary perspective of competent interpretations (Halliday 1994: 32), offering an "explanatory capacity" (Chomsky 1965: 23-24) of grammars and an opening towards a pragmatic approach with regard to teaching as linguistic phenomenon. The attention of the communicative perspective shifted the position of Romanian study from a predominantly analytical and descriptive activity towards anticipated communicative competence as the goal of modern grammar studies (Chafe 1970; Feuillet 1988, 2006), and also towards pragmatics (Levinson 1983; Armengaud 1993; Moescheler 1999).

The formation of a language habit can be equated with forming a concept related to the functioning of the system (the langue/parole dichotomy, a schema 
of communication and its elements: sender, receiver, channel, code, context, and referent), with obtaining a rule that makes possible the recognition of correct pronunciation from the grammatical and semantic point of view, and forming an infinite number of utterances considered correct by Romanian speakers.

"Functional" is a term frequently encountered in modern linguistics. This designates, first of all, the approach taken to language study (Givón 1984, 1990; Dik 1989: 12; Halliday 1994). It refers to the function of communication, taking into account primary roles fulfilled via linguistic units through the communication process and its relevance in transmitting information.

\section{DIFFICULTIES AND TEACHING SOLUTIONS}

At the phonetic level, the main difficulty is functionally distinguishing the values related to the grapheme $i$. Romanian has quantitative and qualitative differences relating to $i$, such as vowel, semivowel, graphic sign, or voiceless final $i$ (a special feature of Romanian).

Slovenian has two types of $i$ with regard to quantity: long $i$ when stressed (Sln. $\sin$ [si:n] 'son') and short $i$ when unstressed (sit [sit] 'full'; Derbyshire 1993: 16). However, Slovenian students have some difficulty in pronouncing the different types of Romanian $i$, which is almost generalized into vocalic $i$.

The values of $i$ in Romanian are: vocalic stressed $i_{1}$ (fir 'wire'); stressed final $i_{2}$ (auzi 'hear') and in some other words such as acri 'sour', aştri 'stars', miniştri 'ministers', or in neologisms ( $k a k i$ 'khaki', taxi 'taxi'); semi-vowel $i_{3}$, found in diphthongs or triphthongs (iei 'you take', leoaică 'lioness', nai 'pan-pipe'); voiceless asyllabic or aphonic $i_{4}$ (pomi 'trees', ficşi 'fixed') or in compound words (oricum 'however'); and $i_{5}$ as a graphic symbol in the groups of letters ci, gi, chi, ghi: treci 'you pass', tragi 'you pull', unchi 'uncle', unghi 'angle'.

The suggested exercises for this issue address the quantitative and qualitative distinction of sound through words in which this sound appears with different values, through distinguishing contexts in which the orthography is relevant for pronunciation ( $p$ omi 'trees' vs. pomii 'the trees'), or through adjectival word order (acești pomi 'these trees' vs. pomii aceştia 'these trees').

To differentiate the quantity and quality of $i$, various values were practiced in contrastive contexts: fraț 'brothers' vs. frații 'the brothers', miniştri 'ministers' vs. miniştrii 'the ministers'. There were also exercises involving syllabic boundaries and changes in the number of syllables in the verb due to verb + clitic patterns, offering the opportunity to observe modifications of $i$ in groups such as verb + pronominal clitic (permiteți 'allow' vs. permiteți-mi 'allow me').

Taking advantage of one similar sound in Slovenian, it was possible to explain the pronunciation of $i$ before the Romanian verb a $f i$ 'to be' and personal pronouns beginning with $e$ : este 'he/she is', el/ea 'he/she'.

Another difficulty at the phonetic level is the articulation of the Romanian sounds $\breve{a}$ and $\hat{\imath}$. Treating the vowels in the central series together with an explanation of the articulation system, it is possible to achieve correct pronunciation of these sounds in exercises that differentiate the degree of mouth aperture 
(very open $a$ as in mal 'shore', medium $\breve{a}$ as in măr 'apple', close $\hat{\imath}$ as in urî 'to hate').

At the suprasegmental level of the morphemes, stress presents difficulties. Misplacement of the accent under the influence of one's native language or other languages (évita 'avoid', pútem 'we can', pérdele 'curtains', sigúr 'certain', stádion 'stadium') were corrected by practicing correct accentuation, pointing out the proper accent position through graphic marking, and emphasizing the various functions of stress as they relate to semantics (ángust 'August' vs. augúst 'majestic'), part of speech (véselă 'happy' vs. vesélă 'dishes'), or verb tense.

The theoretical premises to morphology were that Romanian is a strongly inflected language with a rich inventory of functional categories, and that there is a connection between the classification, inflection, and morphemic structure.

The extremely rich inventory regarding lexico-grammatical categories and subcategories and syntactic functions offers multiple observations and distinctions in functional grammar. For a long time, the morphosyntactic perspective addressed grammar through a concentric approach using parts of speech and syntactic position. Differentiating the parts of speech and their subgroups according to modern linguistic theory (Feuillet 1998) and prototype semantics (Colleman \& Kay 1981; Shibatini 1985; Dubois 1991) made it possible to recognize the groups based on the prototypical dimension of each language (endings for the nominal inflection, suffixes for adjectival and verbal inflection), thus providing an inventory of material for open classes such as clitics, adverbials, and speech markers.

The presentation of theoretical morphology during the first lesson and fixing the correspondence between basic issues at this level (classification, declension, and morphological structure) and specific units (part of speech, grammatical category, and morpheme) made it possible to understand the principle of functioning at the morphological level and to create one teaching strategy that included an approach to morphological analysis or performance at other levels of language (semantic or syntactic).

The study of parts of speech relates to dissociation between what can be inflected and what cannot be inflected, and surprise at the various contextual values that parts of speech have. Teaching and differentiating morphological values in different contexts are therefore absolutely necessary.

In the nominal declension, the most frequent difficulties appear when deciding on the grammatical gender of a noun or adjective; specifically, in selecting an ending. One relatively simple criterion for differentiating gender in Romanian is placement in a diagnostic context (Diaconescu 1972: 71-72). Nevertheless, there are a significant number of nouns whose gender cannot be identified easily (mass nouns and abstract nouns). Correct determination of the grammatical gender of a noun was achieved by combining logical criteria (correspondence between natural gender and grammatical gender), syntactic criteria (occurrence in specific contexts), and semantic criteria (the neuter is essentially a non-animate gender). After presenting an inventory containing prototypical endings for each grammatical gender, the students analyzed various types (i.e., deviation from the prototype) and practiced specific patterns for each type of ending. The difficulty in selecting is caused by homonymous endings (e.g., $-i$ marks the plural for both 
masculine and feminine) as well as by endings within the same gender (e.g., - $e$ and -uri as neuter plural endings).

The lack of definite and indefinite articles in Slovenian causes variation when choosing one of these two forms for nouns. In general, there is a tendency for students to use the noun with the definite article. This tendency is probably linked to imitation or comparison of structures from other languages.

The first explanations relating to the use of the definite or indefinite form of a noun came from the larger context of determination and from the possibility of expressing this category with the help of morphological means (i.e., an article) and lexical means (i.e., an adjective). The various levels of determination that exist in Romanian made it possible to see other problems relating to grammar, semantics, syntax, or linguistic typology and helped in comparatively discussing one issue, the parameter of animacy, which is present in both languages.

Additional criteria were used to distinguish contexts in which the noun appears with the article. It is a well-known fact that in syntactic positions of subject plus direct object the noun appears without the article only in a generic context (Se caută profesor 'A teacher is sought'. Cumpăr pisică 'I am buying cat'). In other situations, the noun generally appears with the article. With occurrence in prepositional contexts, it is possible to differentiate the level of knowing the object (Merg pe stradă. / Merg pe o stradă 'I am walking on a street' vs. Merg pe strada X'I am walking on X Street'). However, there are also prepositional contexts in which the use of an articulated form is obligatory (Scriu cu un creion / creionul 'I am writing with a pencil / the pencil'. Merg cu un prieten / prietenul 'I am walking with a friend / the friend'). The occurrence of the articulated form is also defined by certain adjectival contexts. Thus, if the adjective is placed in front of a noun, it requires the indefinite form of a noun, and for adjectives like insuşi, tot it requires the articulated form of a noun.

The use of the definite article in front of a proper masculine name (lui Vasile 'to Vasile'), an abbreviated feminine name (lui Bety 'to Bety'), a derived name common in both genders (lui Irinel 'to Irinel', lui Catrinel 'to Catrinel') or an invariable name (lui Carmen 'to Carmen') was linked to the Romanian category of animacy and was explained in a personal subgender context.

The conditions for occurrence of the possessive article were assessed using specific syntactic contexts. Multiple morphological values of words with a reduced phonetic body were difficult for one learner to recognize. The first step in understanding this issue was explaining the specific occurrence: for a predicative noun (Casa este a vecinului / a mea 'The house is my neighbor's / mine'), when a genitive or possessive appears in front of the noun (a mea / a părintilor casă 'my / my parents' house'), when an adjective or prepositional attribute is inserted between the noun and genitive or possessive (casa frumoasă / de lemn a vecinului / a mea 'the neighbor's / my beautiful / wooden house'), and in cases when the head noun occurs with the indefinite article (o casă a mea / a vecinului' a house of mine / of my neighbor's').

Explaining the inventory and illustration each characteristic through a relevant context was the first step in recognizing the morphological values of $a$. 
After this step, exercises were used to help the students differentiate between the morphological values and to make sentences for each one.

For adjectives, the first problem was classifying them. A contextual process was used to delimitate the paradigms, making it possible to differentiate groups of adjectives. Special attention was dedicated to endings repeated by the adjective from the noun (o fată frumoasă 'a beautiful girl', unei fete frumoase 'to a beautiful girl') and to limited groups of words that belong to different parts of speech (atât 'this much', putin 'a little', mult 'a lot', tot 'all'), especially the occurrence of one specific form, the genitive-dative plural (atâtor (a) 'to this many', putinor (a) 'to few', multor(a) 'to many', tuturor (a) 'to all') and to coexistence in free variation of the genitive construction and an analytic structure in the accusative (a multi 'of many', a puțini 'of little', a tot 'of all'; Pană Dindelegan 2003: 65-74). Because of the rich declension system in Romanian, it is difficult to understand how the group of pronouns functions, especially the pronominal clitics (Graur 1938: 42-89; Pană Dindelegan 1998: 3-7, 2003: 87-102).

The gradual understanding of morphological notions, the explanation of notions relating to pronominal clitics, and the discussion of specific occurrences in Romanian required many stages of reading: understanding, recognition, and the use of pronominal clitics in various contexts.

The term clitic was rather recently introduced in linguistics (Zwicky 1977, 1983: 502-513) and designates all forms of personal and reflexive pronouns and demonstrative and possessive adjectives that appear in the popular register of languages (ăst- an 'this year', mă-sii 'to his mother'), are marked by loss of accent and implicit syntactic autonomy, and are group together with a "plain" word (a luat-o la sănătoasa 'he ran away' vs. a luat-o de nevastă 'he married her'), sometimes with the amalgamation of morphosyntactic information from both components.

The rich inventory of unstressed forms of personal and reflexive pronouns (Farkas \& Kazasis 1980: 75-82, Niculescu \& Renzi 1991: 123-142) and their morphological, syntactic, and stylistic features became clear in contexts created through comparison with other languages, including Slovenian.

In this context, functional differences look like semantic problems: there is the loss of the referential capacities of a neuter pronoun and of a non-syntactic reflexive (d $\breve{a}-i$ cu bere, dă-i cu vin 'keep on drinking beer and wine' / dă-i cartea copilului 'give the book to the child'), but they can also be perceived from syntactic aspects: the capacity of one form to occur in different syntactic positions. The reflexive pronoun for the dative can be a mark of the reflexive: şi-a inchipuit 'he imagined'; an indirect object or reciprocal structure: şi-a cerut seriozitate 'she asked herself for seriousness', şi-an spus secrete 'they told secrets to each other'; a pronominal attribute (Cristea 1974: 5-14): şi-a spus părerea 'he stated his opinion'; a pragmatic-stylistic aspect: tabla a şters-o cu atentie 'he erased the blackboard attentively'; or neutral and stylistically unmarked: a şters-o englezeşte 'he escaped' (familiar language, slang). The capacity of a reflexive clitic with different senses was also considered important (a duce 'to bring' / a se duce 'to go'; a uita 'to forget' / a se vita 'to look'). 
The presentation of an inventory, the illustration of specific values, and conversation exercises were the methods for understanding the importance of pronominal clitics in Romanian.

The asymmetry of the relative system is also evident in differences in the inventory between the interrogative and relative, such as the compound pronoun ceea ce 'that', which has only a singular form functioning as a relative.

Considering the centre of the sentence, the verb attracts attention in any language through its complex inflectional system, through its variety of forms and possibility for argument coding, and through the double or triple nature of impersonal verbal forms (infinitive, gerund, past participle, and supine).

Regarding classification, there are multiple opinions in Romanian linguistics regarding the number of conjugations. For teaching reasons, the traditional classification of verb conjugation was used, pointing out (where necessary) that there are functional differences in the same class.

The morphemic structure of the present tense was analyzed, highlighting two subtypes of the first and fourth conjugations, named in several Romanian grammars as the strong present (verbs conjugated without a suffix: a cânta 'to sing', a invăț 'to learn', a coborî 'to descend'), as opposed to the weak present (verbs conjugated with a help of suffix: a lucra 'to work', a citi 'to read', a urî 'to hate'). Only practice can help students differentiate these and select and use the correct forms with or without a suffix. For Slovenian students, hesitation in using the suffix (*dorează) resulted from incorrectly classifying a verb into a conjugation type.

The morpheme structure of forms for the past and future, the possibility of occurrence in inverse constructions (fost-am 'I was', fi-voi 'I will be'), and the possibility of expressing the future through different means (the auxiliary a vrea 'to want' + infinitive: voi veni 'I will come', the auxiliary a avea 'to have' + subjunctive: am să vin 'I will come', the auxiliary $o$ + subjunctive: $o$ să vin 'I will come', and forms with apheresis: oi veni 'I might come'; Berea Găgeanu 1978: 68-72) attracted attention at other points of interest in discussions concerning verbal inflections.

Some students' interest in and knowledge of impersonal verbal forms led to detailing some theoretical issues such as the morphological structure and values of the Romanian infinitive (Asan \& Vasiliu 1956: 97-107; Diaconescu 1977), the gerund (Drăghicescu 1990: 303-307) and past participle (Ocheşeanu 1954: 16-21; Stati 1958: 27-30), occurrence of the infinitive without the morpheme a next to the verb: a putea 'to be able to', the syntactic implications of the double nature of the past participle and gerundive forms in Romanian (Pană Dindelegan 1992: 119-121), and comparison of the occurrence of the supine in Romanian and Slovenian.

The invariable parts of speech represent another area of interest in the study of Romanian as a foreign language. In adverb use there was an attempt to correct some typical mistakes such as incorrect adverb position in compound verbal forms (*am bine ştiut 'I well knew'), the occurrence of the adverb in principal context (lucru bine ştiut 'a well-known fact'), and the thematic word order of interrogative adverbs (Unde ai fost? 'Where were you?'). Special attention was turned to the subclass of adverbials (Ciompec 1985: 81-83) and to various possibilities of expressing the semantic category of proximity through an adverbial. 
The prepositional system and the prepositions' capacity to affect syntactic functions due to their meaning and pragmatic behavior revealed more difficulties. The first issue was to become familiar with special semantic features and cases with a preposition, and with the occurrence of articulated or non-articulated nouns after certain prepositions.

It was suggested that students classify prepositions using the generative grammar point of view, with prepositions demanded by the verbal system (convituieşte cu 'lives with', constă în 'consists of', depinde de 'depends on', se erijează $\hat{i n}$ 'pretends to') or prepositions that function as the center of a syntactic group.

Comparative analysis exercises (deasupra casei 'over the house', acestuia 'over him', alor mei 'over mine', cui 'over who', nimănui 'over nobody', deasupra-i 'over him', deasupra mea 'over me') made evident the difference between case and morphological values regarding subordinated parts of speech (nouns, pronouns, and adjectives).

The possibility of free variation with prepositions (Sunt in/la Paris. 'I am in/ at Paris' Ne vedem in/pe zece septembrie 'I will see you in/on the 10th of September') and their occurrence in specific verbal contexts (Vin din parc 'I am coming from the park', Merg spre facultate 'I am going to the faculty', Plec de la teatru 'I am leaving from the theatre') made it possible to discuss details about the Romanian preposition (Frățilă 1905: 36-37; Pană Dindelegan 2003: 165-182).

In syntax, one of the most frequently discussed issues was the doubling of indirect and direct complements. The first step regarding the teaching approach to this problem consisted of understanding the functions related to pronominal clitics in Romanian. The use of the morpheme pe and doubling the clitic complement were explained using the Romanian category of animacy and through comparison with Slovenian, in which accusative animate nouns have the same form as the genitive, in contrast to inanimate nouns. The discussion of this problem involves a large number of morphological, syntactic, and pragmatic factors. Proceeding from a simple context (Citesc cartea 'I read the book' / Cartea o citesc 'It is the book that I am reading' / Cartea am citit-o ieri 'I read the book yesterday', $O$ ştiu pe Milica 'I know Milica', L-am ajutat pe Goran 'I helped Goran', Nu am supărat pe nimeni 'I did not upset anyone'), some rules were formulated to distinguish the prepositional from non-prepositional context, departing from the morphological quality of the word that appears in direct-object position, from word-order influence in a doubling phenomenon, from the animate or inanimate character of nouns, or from the speaker's preference for precise pragmatic selection (Frătilă 1905: 36-37; Pușcariu 1922: 563-564; Drăganu 1943: 42-46; Graur 1945: 97-102; Tiktin 1945: 112-124; Graur 1969: 89-90; Guțu Romalo 1973: 165-167; Doca 1989: 10-17; Manoliu-Manea 1993: 92-98; Ionescu 1995: 65-76; Draşoveanu 1997: 107-112; Avram 2001: 243-245; Cornilescu 2001: 25-40; Pană Dindelegan 2003: $165,182,226)$.

Another important difficulty is the rich inventory of syntactic linking words. For example, the subordinate clause of cause has many specific and multifunctional conjunctions: deoarece, pentru că, fiindcă, intrucât, din cauză că, din pricină că, că 'because', dacă 'if'. 
Various sentences were suggested to differentiate the usage of these conjunctions and their occurrences were discussed.

At the lexical level, there was a constant tendency to adapt words from Romanian to the word-formation system in Slovenian through the replacement of suffixes (e.g., adaptacija for Romanian adaptare 'adapting'). The shared Slavic lexical inventory, even if it presents some phonetic differences or stylistic limitations, helped when identifying a particular semantic or lexical item. Knowledge and comparison of the etymon represented a modality for identifying the common meaning in both languages.

\section{CONCLUSION}

Although the two languages are from two different language groups, they both have a shared lexicon; in Romanian this shared lexicon was motivated by Slavic influence over the centuries. Both languages also have some modalities in common for expressing some semantic categories (impersonal, possession), as well as similar parts of speech (reflexive pronouns).

Knowledge of both languages, comparison with other Romance or Slavic languages, and closer examination of general linguistic theory and foreign language acquisition theory facilitate finding optimal modalities for accessing content in coherent instructional manners.

\section{REFERENCES}

ANDREWS, S. (2003) Special issue: Teacher Language Awareness. Language Awareness $12(2): 79-142$.

ARMENGAUD, F. (1985) La pragmatique. 1st ed. (3rd corr. ed. 1993). Paris: Presses Universitaires de France.

ASAN, F./L. VASILIU (1956) Unele aspecte ale sintaxei infinitivului. Studii de gramatică 1: 97-107.

AVRAM, M. (2001) Gramatica pentru toți. Bucharest: Editura Humanitas.

BEREA GĂGEANU, E. (1978) Viitorul în limba română, Typescript. Bucharest: University of Bucharest.

CHAFE, W. (1970) Meaning and the Structure of Language. Chicago: University of Chicago Press.

CHOMSKY, N. (1965) Aspects of the Theory of Syntax. Cambridge, MA: MIT Press.

CILIANU-LASCU, C. (1986) La nominalisation des verbes de changement d'etat en roumain et en française. Analele Universității Bucureşti. Limba şi literatura română 35: 61-63.

CIOMPEC, G. (1985) Morfosintaxa adverbului românesc. Sincronie şi diacronie. Bucharest: Editura Ştiințifică şi Enciclopedică. 
CORNILESCU, A. (2002) Observații privind interpretarea acuzativului prepozițional în limba română. Actele Colocviului catedrei de limba română, 22-23 noiembrie 2001. Bucharest: Bucharest University Press: 25-40.

COTS, J./E. ARNO (2005) Integrating Language Teachers' Discipline Knowledge in a Language Course. In N. Bartles, ed. Applied Linguistics and Language Teacher Education. New York: Springer: 59-78.

CRISTEA,T (1974) Remarques sur le datif possesif en roumain et en français. Revue roumaine de linguistique 10: 5-14.

DERBYSHIRE, W. (1993) A Basic Reference Grammar of Slovene. Columbus, OH: Slavica.

DIACONESCU, P. (1970) Structură şi evoluție în morfologia substantivului românesc. Bucharest: Editura Academiei

DIACONESCU, I. (1977) Infinitivul în limba română. Bucharest: Editura Ştiințifică şi Enciclopedică.

DIK, S. C. (1989) The Theory of Functional Grammar. Dordrecht: Foris Publications.

DOCA, G. (1989) Pe + obiect direct: o abordare psiholingvistică. Analele Universității Bucureşti. Limba şi literatura română 38: 10-17.

DONMALL, B. G. (ed.) (1985) Language Awareness: LCNE Reports and Papers 6. London: CILT.

DRĂGANU, N. (1943) Morfemele româneşti ale complementului în acuzativ şi vechimea lor. Posthumous work. Bucharest.

DRĂGHICESCU, J. (1990) Remarques sur le construction "gerunziu cu acuzativ." Revue roumaine de linguistique 35(4-6, Jul.-Dec.): 303-307.

DRAŞOVEANU, D. (1997) Flectivul pe vs. prepoziția pe. In Teze şi antiteze in sintaxa limbii române. Cluj-Napoca: Editura Clusium: 107-112.

FARKAS, D./K. KAZASIS (1980) Clitic Pronouns and Topicality in Romanian. In J. Kreiman and A. Ojeds, eds. Papers from the 16th Regional Meeting of the Chicago Linguistic Society. Chicago: Chicago University Press, 75-82.

FEUILLET, J. (1988) Introduction à l'analyse morphosyntaxique. Paris: Presses Universitaires de France.

FEUILLET, J. (2006) Introduction à la tipologie linguistique. Paris: Honoré Champion Editeur.

FRANK, C./M. RIVONLUCRI (1983) Grammar in Action: Awareness Activities for Language Learning. Englewood Cliffs, NJ: Prentice Hall.

FRĂT,ILĂ, V. (1905) Sensul şi întrebuințarea prepozițiunilor în limba română. Galați.

GIVÓN, T. (1984, 1990) Syntax. A Functional-Typological Introduction. 2 vol. Amsterdam: John Benjamins.

GRAUR, A. (1938) Les verbes "réfléchis" en roumain. Bulletin linguistique 6: 4289.

GRAUR, A. (1945) Contribution à l'étude du genre personnel en roumain, Bulletin linguistique 13: 97-107. 
GRAUR, A. (1969) Reluarea complementului. Limba română 18(1): 89-90.

HALLIDAY, M. A. K. (1994) An Introduction to Functional Grammar. London: Arnold Heder Hedline Group.

HAWKINS, E (1984) Awareness of Language: An Introduction. Cambridge: Cambridge University Press.

IONESCU, E. (1995) A HPSG Approach to Accusative Clitic Doubling in Romanian. Analele Universității Bucureşti. Limba şi literatura română 48: 65-76.

JAMES, C./P. GARRET (eds) (1992) Language Awareness in the Classroom. London: Longman.

LEVINSON, S. (1983) Pragmatics. Cambridge: Cambridge University Press.

MOESCHLER, J. (1996) Theorie pragmatique et pragmatique conversationnelle. Paris: Armand Colin.

NICULESCU, A./L. RENZI (1991) Pronoms personnels clitiques possessifs en roumain et dans les langues balkaniques. Modèles linguistiques 13(2): 123-142.

OCHEŞEANU, R. (1954) Despre valoarea verbală şi adjectivală a participiului. Limba română 3(6): 16-21.

PANĂ DINDELEGAN, G. (1992) Sintaxă si semantică, Typescript. Bucharest: University of Bucharest.

PANĂ DINDELEGAN, G. (1998) Capcane ale gramaticii (II): forme pronominale atone cu funcție sintactică sau fără funcție sintactică? Limba şi literatura română 27(2): 3-7.

PANĂ DINDELEGAN, G. (2003) Elemente de gramatică. Dificultăţi, controverse, noi interpretări. Bucharest: Editura Humanitas.

PUŞCARIU, S. (1922) Despre pe la acuzativ. Dacoromania 2: 563-564.

SCHMIDT, R. (ed.) (1995) Attention and Awareness in Foreign Language Learning. Honolulu: University of Hawaii at Manoa.

STATI, S. (1958) Valorile participiului. Limba română 7: 27-30

SVALBERG, A. (2007) Language Awareness and Language Learning. Language Teaching 40: 287-308.

TIKTIN, H. (1945) Gramatica română. Etimologia şi sintaxa. Revised 3rd ed. Bucharest: Tempo.

ZWICKY, A. M. (1977) On Clitics. Bloomington, IN: Indiana University Linguistics Club. 


\section{ABSTRACT}

\section{Some difficulties experienced by slovenian students learning Romanian}

This article presents some of the difficulties that arose for students during courses in Romanian language, culture, and civilization at the University of Ljubljana, Slovenia, and suggests some teaching solutions tested in the classes. Proceeding from the framework of functional-cognitive grammar, the solutions that were chosen for interpreting and correcting students' expression combine semantic, teaching, and pragmatic criteria. The analysis covers frequent mistakes and the most characteristic mistakes observed in Slovenian students' speech, and the most appropriate solutions are suggested for them. This article represents a starting point for a Romanian textbook tailored to Slovenian students.

Keywords: difficulties, functional grammar, Slovenian students, Romanian, methods, teaching solutions.

\section{POVZETEK}

\section{Nekatere težave slovenskih študentov, ki se učijo romunsko}

Avtor v članku predstavlja težave, na katere so študenti Filozofske fakultete Univerze v Ljubljani naleteli med učenjem romunskega jezika in predlaga nekaj rešitev, ki so bile preizkušene v razredu. Rešitve, ki jih je uporabil za interpretacijo in popravljanje izražanja študentov vključujejo semantične, pedagoške in pragmatične kriterije ter izhajajo iz funkcionalno- kognitivne slovnice. Analiza zajema pogoste in najbolj značilne napake, ki jih je avtor opazil v govoru slovenskih študentov. Članek predstavlja izhodišče za učbenik romunščine, ki bo prirejen posebej za slovensko publiko.

Ključne besede: Težave, funkcionalna slovnica, slovenski študenti, romunščina, metode, pedagoške rešitve 